\title{
画像解析手法を用いた密度成層場における 噴流の海水混合評価に関する研究
}

\author{
遠藤 徹 1 ・古城 鉄也 2 \\ 1正会員 大阪市立大学大学院講師 工学研究科（†558-8585 大阪市住吉区杉本3-3-138） \\ E-mail:endo@urban.eng.osaka-cu.ac.jp \\ 2正会員 東亜建設工業株式会社 湾奥部浅場造成作業所（干136-0075 東京都江東区新砂3-11-10） \\ E-mail:t_kojou@toa-const.co.jp
}

\begin{abstract}
閉鎖性海域の水質悪化は著しく, 特に港湾海域では密度成層の発達による底層水の貧酸素化が深刻な問 題となっている，成層場を緩和する海水混合技術が多く開発されているが，密度場の流体運動は時空間的 に複雑な挙動を示すため，現地に適用する際には事前に混合効果を把握しておく必要がある。本研究では， 密度場に噴流を作用させた水理実験を実施し, 画像解析手法により海水混合特性について検討した。

同条件の成層場に対して異なる噴流を作用させた結果, 噴流リチャードソン数により混合効果を整理で きる可能性があることが示唆された。また，成層場の形状の異なる場に同条件の噴流を作用させた結果， 噴流の発達領域が広範囲に及ぶように噴流を作用させることでより効果的に海水が混合できることが明ら かとなった。
\end{abstract}

Key Words : LIF, density stratified field, jet, water mixing

\section{1. はじめに}

海水交換が乏しく希䣋拡散効果の低い閉鎖性海域の水 質悪化は著しく，様々な環境問題が発生している．特に 港湾海域では，夏季に発生する底層水の貧酸素化が深刻 である．遠藤ら”が通年にわたって実施したDO濃度の鋁 直分布の実測結果によると，堺泉北港では春から晚秋に かけて慢性的な貧酸素状態に陷っていた，底層水の貧酸 素化は水域生態系に影響を及ぼすだけでなく，底層の嫌 気化により硫化水素などの有毒ガスの発生や内部負荷の 増大など，沿岸域の水質環境にも深刻な影響を及ぼすこ とになり，閉鎖性海域の環境保全には貧酸素化の改善が 重要な課題といえる.

貧酸素化の要因として，夏季に発達する密度成層が挙 げられる．港湾海域では夏季になると日射や降雨の影響 により強固な密度成層が発達寸るため, 鉛直方向の海水 混合が制限され底層への酸素供給が遮断されることとな る.このため, 密度成層を緩和する海水混合促進技術が 多く開発されている，たとえば，海岸構造物に作用寸る 波浪エネルギーを利用して構造物前面部の海水混合を促 進する手法が提案されている2゙, 3)。しかしながら, 密度 場の流体運動は時空間的に複雑な挙動を示寸ため, 当初 期待していた改善効果が得られない場合が多々ある。ま

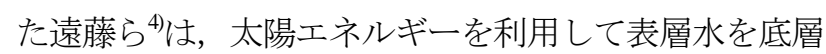

に供給する装置を作成し現地実験を実施したが，混合範 囲は放出口近傍に限定されていた．このように，波浪や 太陽光などのような自然エネルギーを利用する場合には, 利用できるエネルギーに対してどのくらいの効果が得ら れるのか事前に把握する必要がある。一方，電力により 水流発生装置を稼働して水域の鉛直混合を促進する手法 5) 6も提案されており，一定の改善効果が報告されてい る. しかしながら, この場合も装置を稼働するための電 カコストを低減するためには, 密度成層場に対する海水 の混合特性を事前に把握し，対象海域に応じた設計や配 置を検討することが重要となる.

これまでに海水混合促進技術の混合効果について数值 計算や水理実験による検討が行われている. ただし，こ れらの水理実験では, 各地点における濃度や速度の時間 変化を計測器で計測するものであった，このため，多点 で計測するなどの工夫は行われていたが，空間的な定量 評価には至っておらず，噴流そのものの効果や連行現象 の発達過程を定量的に評価することが困難であった. こ のような中, 画像処理と可視化技術の発達に伴い, 空間 的な流体運動の可視化計測が可能となってきた. 特に, 密度場など時空間的に流体運動が変化するような現象を 把握するには有効な手法である. 古城ら》は, 蛍光染料 である Rhodamine B を密度情報の媒体とし，撮影に民生 用のカラーC-MOS カメラを用いた流体密度の画像計測 
手法を開発し，密度成層場に噴流が作用した際の海水混 合メカニズムについて時空間的に検討した.

そこで本研究では，水理実験により密度成層場に噴流 を作用させ，画像解析手法により密度成層場の密度の時 空間変化を計測し，密度構造と噴流による海水混合効果 について検討することを目的とした。

\section{2. 画像解析手法}

流体密度の空間分布の計測には，古城らつと同様にレ ーザー励起蛍光法（LIF : Laser -Induced Fluorescence）を用 いた．この手法は，蛍光剤を溶解させた流体にレーザー 光を照射したときに励起される蛍光強度から蛍光染料の 濃度分布を計測するものである. 本計測手法は前述した ように，海水混合の空間変化を面的に捉えることが可能 であるとともに，計測器自体が流体運動に影響を及ぼさ ないという利点を有しており，本研究で扱う噴流の海水 混合効果を評価するのに適している.

本研究で害施したLIFの画像解析手法の手順を図-1に 示す. 蛍光染料にはRhodamine Bを用いた。これは,

Rhodamine Bの吸収スペクトルのピーク $(550 \mathrm{~nm})$ が本研 究で用いるレーザー光の波長 $(532 \mathrm{~nm})$ に近く発光効率 が高いこと，また，照射するレーザー光が緑色であるの に対してRhodamine Bは赤色の蛍光を示寸ため, 得られ た撮影画像のRed-RGB值を解析に用いればレーザー光の 影響が無視できるという利点がある.

密度成層場の形成には，食塩により密度を調整した高 密度水之低密度水を用い, 高密度水之低密度水の

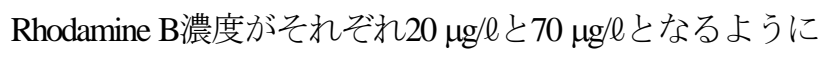
Rhodamine Bを溶解した。これは，事前に実施した実験 から， Rhodamine B濃度が10 80 $\mu \mathrm{g} / \mathrm{e}$ 程度の濃度域におい て, Rhodamine B濃度と撮影されたRed-RGB值に線形関係 が見られたためである．実験開始時には，レーザーを水 面上から照射し，染料の蛍光強度をHDビデオカメラで 撮影した. 図-2(a)に撮影した元画像を示す．元画像より， Rhodamine B濃度が高い上層が明るく, 濃度が低い下層 が暗くなっていることが確認できる，その後，元画像か らRed-RGB值を抽出した. 図-2(b) にRed-RGB值の分布を 示寸.この画像には, 壁面や気泡などに起因する光学ノ イズや，光の減衰による偏光が含まれる，そこでこれら の影響を除去するために, 前者には半径5 pixelのメディ アンフィルターを適用し, 後者にはBeer-Lambert の法則 を適用した. 最後に, Red-RGB值からRhodamine B 濃度 を計算し, 予め求めておいた補正関数により Rhodamine B濃度から塩分に換算し, その後, 流体密度を推定した。 ここで，本手法では塩分分布をRhodamine Bの蛍光強度 から間接的に求めているが，食塩とRhodamine B溶液の

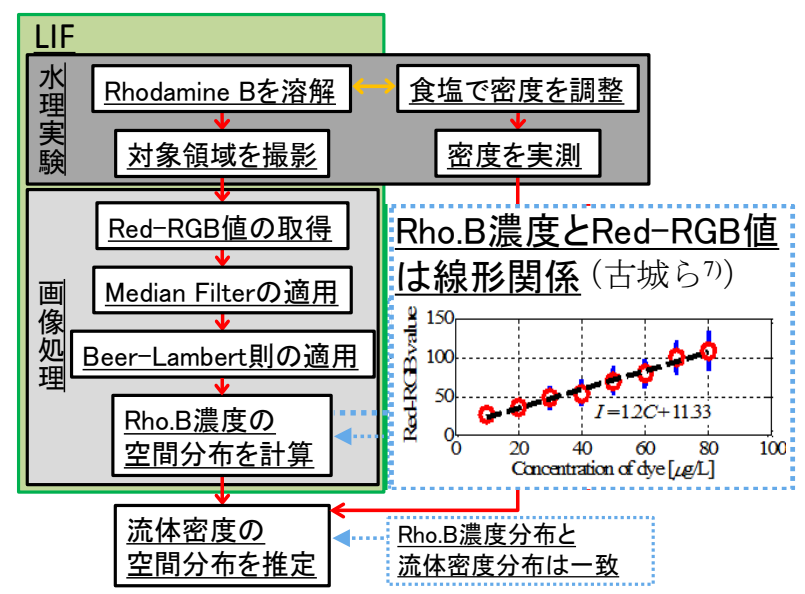

図-1＼cjkstart画像解析による流体密度分布計測の流れ

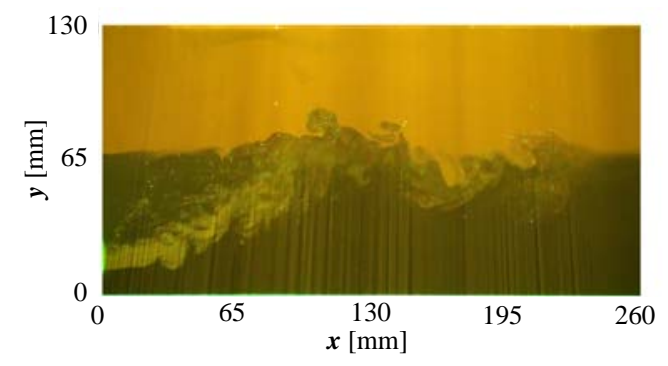

(a) 撮影した元画像

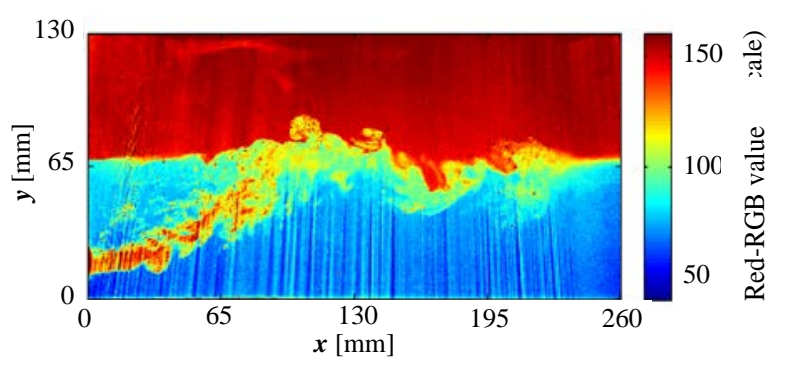

(b) 元画像の Red-RGB 值の分布

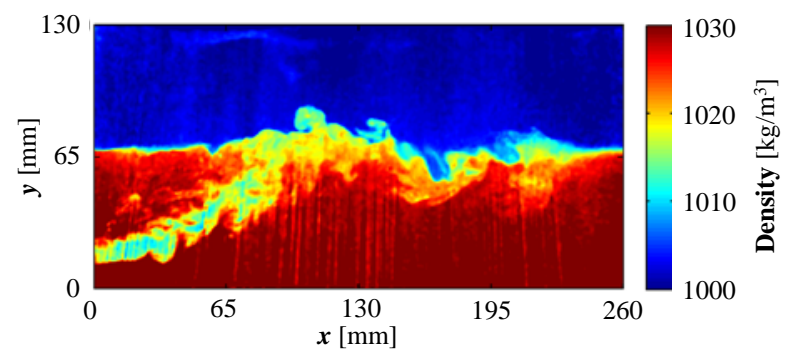

(c) Red-RGB 值から推定した密度分布

図-2＼cjkstart画像解析による密度分布の推定手順

シュミット数（動粘性係数と拡散係数の比）が近いため, 両者の拡散挙動は同一のものと仮定している. また,

Rhodamine Bは塩化物の影響により蛍光強度が低下寸る ため, 食塩水に溶解する際には少量のカルキ抜き剤を溶 解した。このようにして計測された密度分布を, 図-2 (c) に示す．下層において，レーザー光の散乱に起因する筋 がみられるが，噴流による流体の混合の様子を面的に捉 
表-1 実験条件

\begin{tabular}{|c|c|c|c|c|c|c|c|}
\hline Case & $\begin{array}{l}\text { 噴流密度 } \\
\rho_{\mathrm{I}}\left[\mathrm{kg} / \mathrm{m}^{3}\right]\end{array}$ & $\begin{array}{l}\text { 上層密度 } \\
\rho_{\mathrm{L}}\left[\mathrm{kg}^{3} \mathrm{~m}^{3}\right]\end{array}$ & $\begin{array}{l}\text { 下層密度 } \\
\rho_{H}\left[\mathrm{~kg}^{3} \mathrm{~m}^{3}\right]\end{array}$ & $\begin{array}{l}\text { 上層厚 } \\
h_{L}[\mathrm{~mm}]\end{array}$ & $\begin{array}{l}\text { 下層厚 } \\
h_{H}[\mathrm{~mm}]\end{array}$ & $\begin{array}{l}\text { 躍層厚 } \\
h_{P}[\mathrm{~mm}]\end{array}$ & $\begin{array}{c}\text { 噴流リチャードソン数 } \\
R i_{J} \\
\end{array}$ \\
\hline A1 & 1000 & & & & & & 0.287 \\
\hline A2 & 1005 & & & & & & 0.236 \\
\hline A3 & 1011 & 1000 & 1028 & 65 & 65 & 0 & 0.174 \\
\hline A4 & 1016 & & & & & & 0.123 \\
\hline A5 & 1022 & & & & & & 0.062 \\
\hline B1 & \multirow{4}{*}{1000} & \multirow{4}{*}{1000} & 1019 & 40 & 40 & 50 & 0.196 \\
\hline B2 & & & 1016 & 65 & 65 & 0 & 0.166 \\
\hline B3 & & & 1016 & 40 & 90 & 0 & 0.166 \\
\hline B4 & & & 1025 & 90 & 40 & 0 & 0.257 \\
\hline
\end{tabular}

えることができている.

\section{3. 水理実験}

水理実験は，図-3に示すような長さ1,800 mm，高さ300 $\mathrm{mm}$, 幅250 mmのアクリル水槽を用いて実施した. 水槽 内に, Rhodamine Bを溶解した高密度水 : $\rho_{H}$ と低密度水 : $\rho_{\mathrm{L}}$ を注ぎ，全水深が $H=130 \mathrm{~mm}$ となるように密度成層場 を形成した。噴流は，密度を調整した流体を貯めたタン クから水中ポンプを用いて水底に設けた放出口から放出 することで作用させた．放出口の径は13 mmとし，実験 水槽の水底から13 mmの位置に下端を設置した。ここで 図-3 (b) に示すように，放出口の先端部から鉛直におろ した水底の地点に原点をとり，噴流方向に $x$ 軸を，また， 水底から鉛直上向きに $y$ 軸を設定した. 水槽の上部から $\mathrm{Nd}$ : YAGレーザーを $2 \mathrm{~mm}$ 厚のシート状で $x$ 軸方向に照射 し，噴流による密度成層場の混合の様子をC-MOSカラ 一カメラ (SONY社製，HDR-XR520V）で撮影した。撮 影された動画から任意の時間の画像を取りだし，前述の 画像解析手法により流体密度の時空間変化を計測した.

実験では，作用させる噴流と密度場による混合状況の 違いについて検討するため, 表-1に示寸 9 通りの条件で 実施した。 まず，同条件の密度成層場に対して流体密度 が異なる噴流を作用させた場合に海水混合効果にどのよ うな違いがあるのかを検討するため, Case Aでは5 通り の条件を設定した，さらに，実海域においては海域の環 境条件や季節によって上層と下層の層厚などの成層の構 造が異なるため, 成層場の形状の違いによる噴流の混合 効果について検討するために, Case Bでは噴流の流速と 密度は同じで成層構造を変化させた 4 通りの条件を設定 した.

ここで，噴流の諸元を表す指標として噴流リチャード ソン数:Ri 在次式のように定義した。

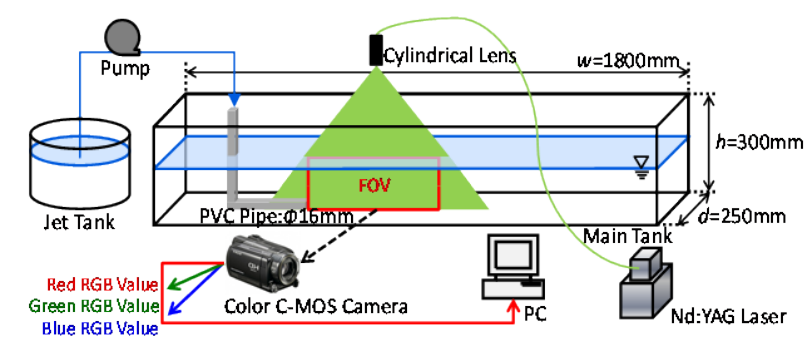

(a) 害験装置

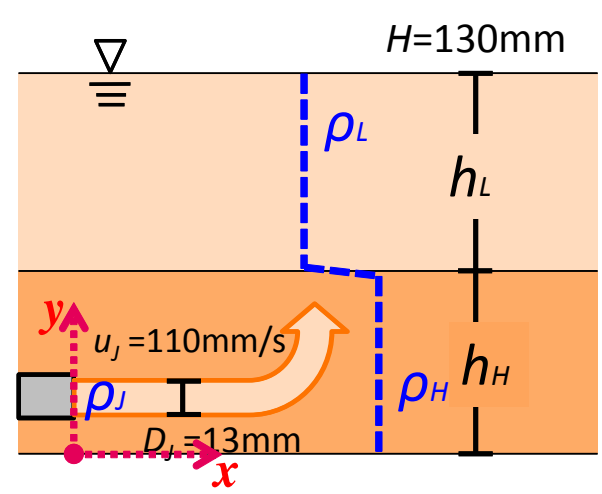

(b) 噴流と密度成層場

図-3＼cjkstart水理実験装置の概要

$$
R i_{J}=\frac{\left\{\left(\rho_{H}-\rho_{J}\right)\right\} g D_{J}}{u_{J}^{2}}
$$

ここで， $\rho_{H}$ は下層の流体密度， $\rho_{J}$ は噴流の流体密度， DJは放出口の高さ， $u_{J}$ は噴流の流速である.

\section{4. 実験結果および考察}

（1）噴流による密度場の変化

図-4に，Case A1の成層場の混合の様子を示す．同 図 (b)より，放出口から放出された噴流は浮力の影響に 


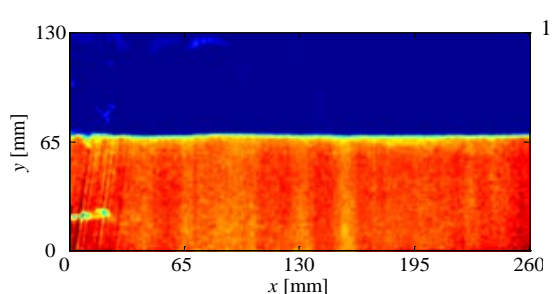

(a) 0 秒

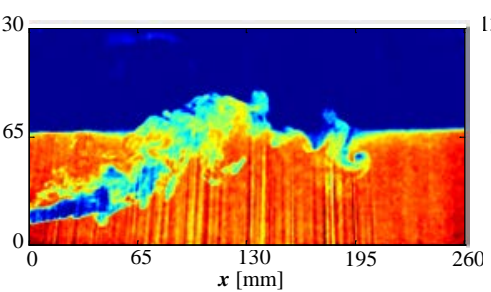

(b) 噴流作用 30 秒後

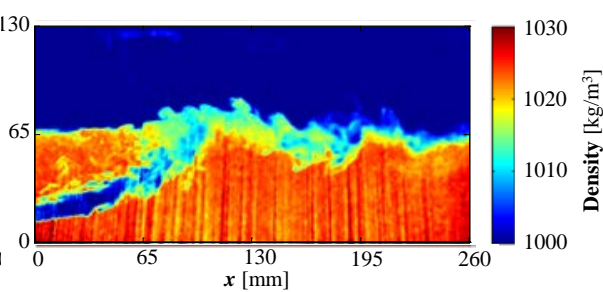

(c) 噴流作用 60 秒後

図-4 噴流による密度場の混合の様子（Case A1）

より徐々に上昇し，躍層間で激しく混合している様子 が確認できる，その後，同図 (c)より，上層と下層の流 体を混合しながら躍層間を沖向きに進んでいる様子が 確認できる，以上より，本画像計測手法で噴流による 成層場の海水混合を評価することが可能であると言え る.

\section{（2）噴流の違いによる混合特性}

同条件の密度場に対して異なる条件の噴流を作用させ た場合のCase Aに着目する。噴流を作用させてから120 秒経過後の各ケースの混合状況を図-5に示す．Rijが最も 大きいCase A1が良く混合しており，RiJが小さくなるに つれて混合具合も穏やかになる傾向が見られる。これは， $R i_{J}$ が小さい場合は噴流流体と下層流体との密度差が小 さいため, 噴流に作用する浮力の影響が小さくなり成層 場の混合効果も小さくなったためと考えられる.

次に, 流体密度が $\rho_{H} / \rho_{H O}<0.8$ ( $\rho_{\mathrm{HO}}$ は初期の下層流体 密度）となる領域を混合面積: Eと定義し, 各ケースの 混合面積の時間変化を図-6 に示す.ここで, 縦軸の混 合面積は撮影領域の面積 : Aで無次元化している. 同困 より, 混合面積は噴流を作用させてから線形的に増加し, 約10 秒経過後には混合面積の時間変化がほぼ定常状態 になっていることが確認できる．また，Ri ど定常状態となった時の混合面積も大きくなる傾向が見 られた。

続いて，撮影領域内の水平平均密度分布から次式のよ うに定義したポテンシャルエネルギー：Фにより成層場 の混合効果について検討する.

$$
\Phi=\int_{0}^{w} \phi \mathrm{d} x \cdot d
$$

ここで， $w$ は撮影領域の幅， $d$ は水槽の奥行， $\phi$ は $x$ 軸上 の任意点における鉛直密度分布から算出した水柱ポテン シャルエネルギーであり, 次式で表される.

$$
\phi=\int_{0}^{H}\{(\bar{\rho}-\rho) \cdot g y\} \mathrm{d} y
$$

ここで， $g$ は重力加速度， $\rho$ は任意点における流体密度， $\bar{\rho}$ は $x$ 軸上の任意点における密度の鉛直方向の平均值で,

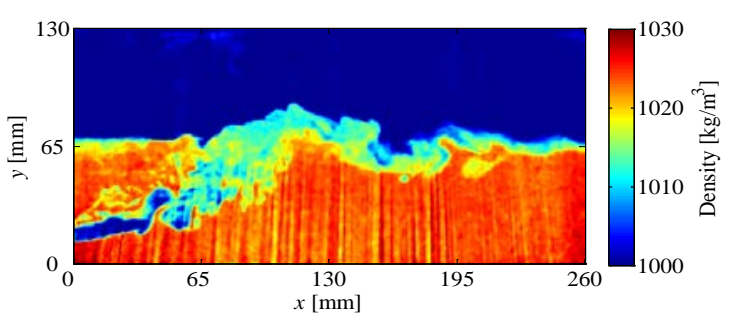

(a) Case A1

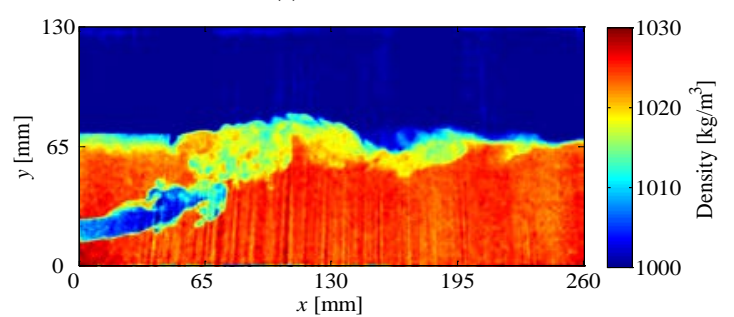

(b) Case A2

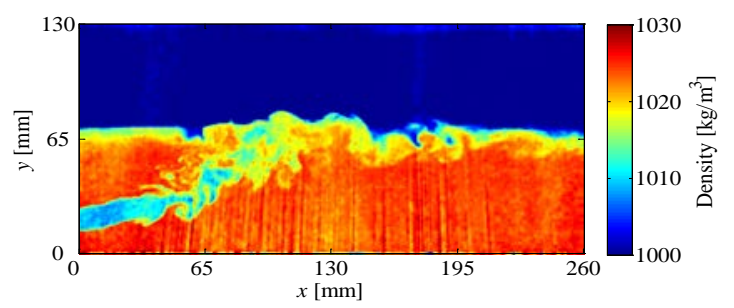

(c) Case $\mathrm{A} 3$

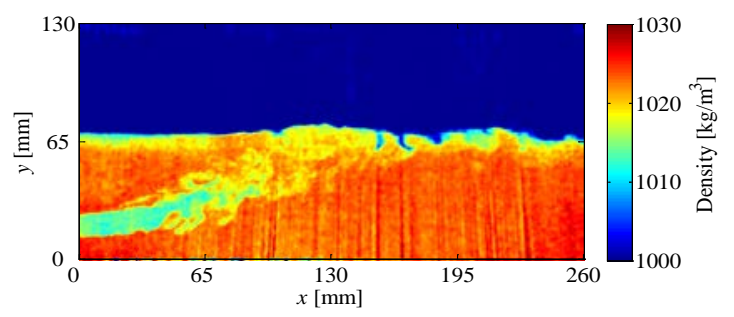

(d) Case A4

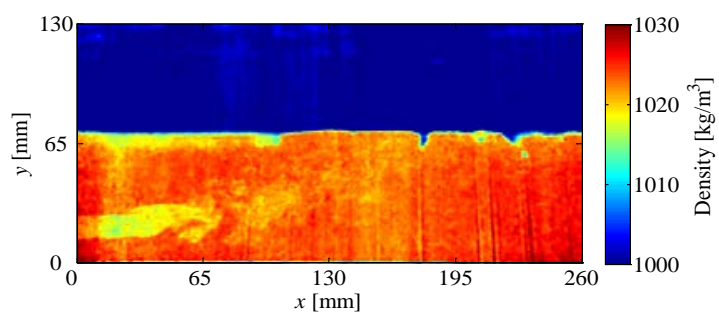

(e) Case A5

図-5 噴流作用 120 秒後の Case A の混合の様子 


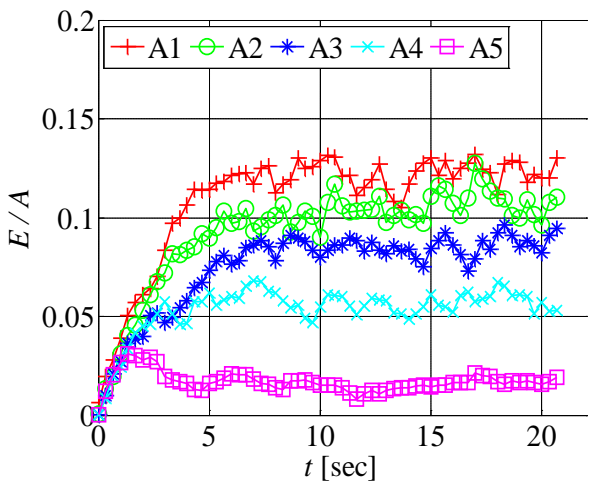

図-6 Case Aの混合面積の時間変化

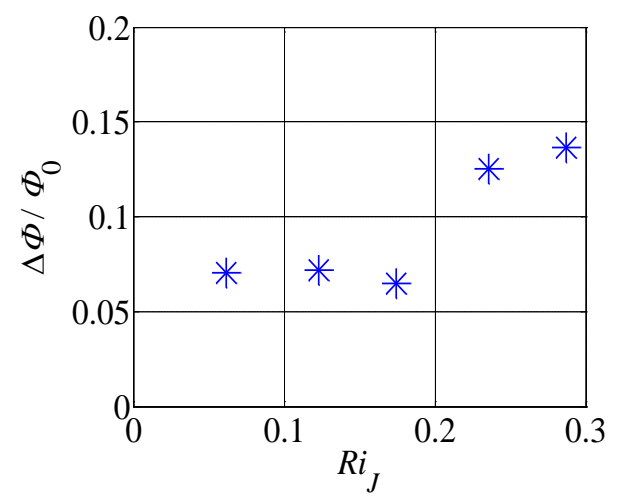

図-7 Case Aのポテンシャルエネルギーの変化量 $\Delta \Phi / \Phi_{0}$ とリチャードソン数 $R i_{J}$ の関係

$$
\bar{\rho}=\frac{1}{H} \int_{0}^{H} \rho d y
$$

である，中は成層場の持つ強度をエネルギーとして表現 した指標であり，理論的にはその成層場の密度分布を均 一にするのに必要なエネルギーとして知られる.

噴流が作用することによって初期のポテンシャルエネ ルギー $\Phi_{0}$ から変化した量を $\Delta \Phi\left(=\Phi_{0}-\Phi\right)$ として， $\Delta \Phi$ と $R i_{J}$ との関係を図-7に示寸。ここで， $\Delta \Phi$ は初期の $\Phi_{0}$ で無 次元化している，同図より，Risが0.2以下であれば $\Delta \Phi$ は ほぼ一定の值を取り，Ri が 0.2 より大きな噴流を作用さ

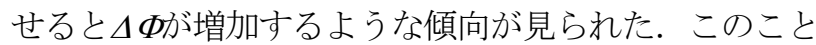
から，RiJがある值より小さい範囲は成層場のポテンシ ヤルエネルギーの変化量は同程度であるが，ある值を超 えるとRi $、$ に応じて成層場が混合しや寸くなることを意 味している.

以上より，Ri $i_{J}$ 対する混合面積とポテンシャルエネ ルギーの変化量で異なる傾向が見られたものの，海水混 合を促進するためには噴流のRi ましいということが明らかとなり，RiJで密度成層場の 混合効果を整理することが可能であることが示唆された。 ただし，本研究の実験ケース数では定量的な結論には至 らず，今後は流速なども変化させた実験ケースを実施す ることによる詳細な検討が必要であるといえる.

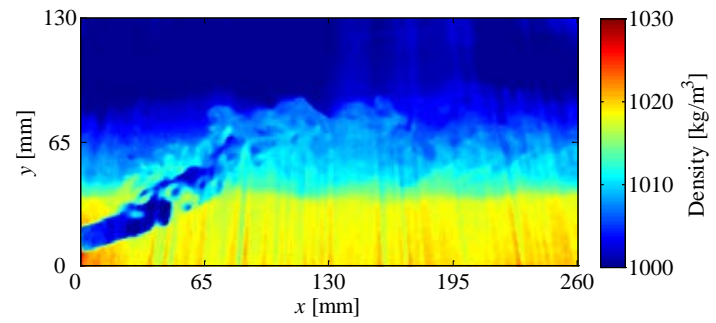

(a) Case B1

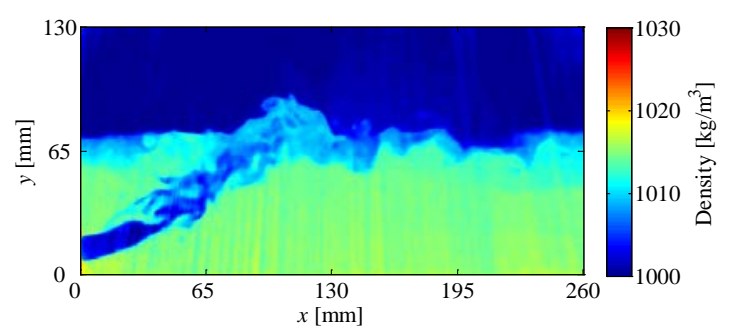

(b) Case B2

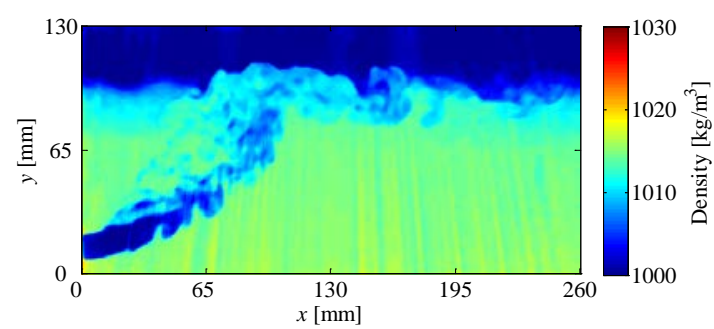

(c) Case B3

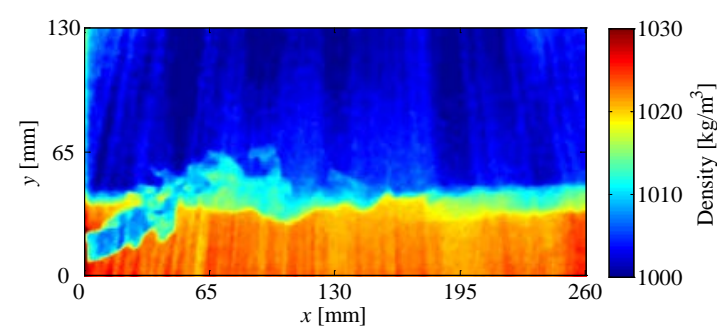

(d) Case B4

図-8 噴流作用 120 秒後の CaseB $の$ 混合の様子

\section{（3）成層場の形状の違いによる混合特性}

形状が異なる成層場に対して同条件の噴流を作用させ たCase Bに着目する．噴流作用 120 秒後のCase Bの混合状 況を図-8に示す．成層の上層と下層の間に躍層を有する Case B1は噴流密度に近い上層まで上昇するため躍層間 での混合が小さい。一方，下層厚が厚いCase B2やB3は 下層厚の薄いCase B4に比べて発達領域が広範囲に形成 されていることが確認できる.

続いて，図-9に $x=240 \mathrm{~mm}$ 地点における水柱ポテンシ ヤルエネルギー： $\phi$ の時間変化を示す。ただし，縦軸 $\phi$ は初期水中ポテンシャルエネルギー： $\phi_{0}$ で無次元化して ある. 同図より時間の経過とともに徐々に水柱ポテンシ ヤルエネルギーが小さくなっていることが確認できる. 


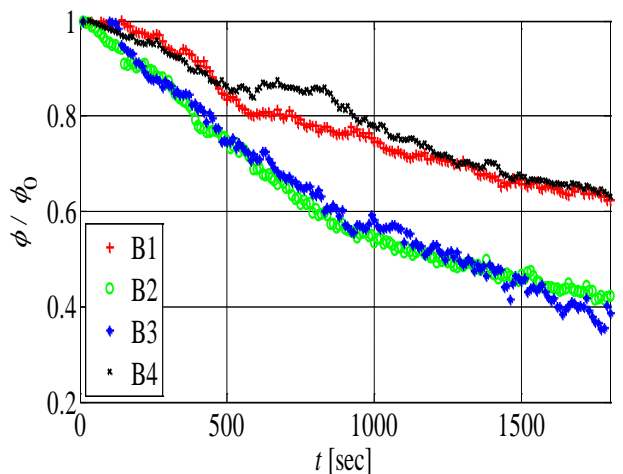

図-9 $x=240 \mathrm{~mm}$ 地点における水柱ポテンシャルエネル ギー $\phi$ の時間変化

ただし，長時間噴流を作用させていると下層厚が薄い Case B1，B4よりも，下層厚が厚いCase B2，B3の方が混 合効果が大きくなる傾向が見られる．これはCase B1， B4のように下層厚が薄い場合は噴流の発達領域が放出 口近傍に限定されるため，噴流の場を乱す効果が低下し たためであると考えられる，このことから，同条件の噴 流で効果的に海水を混合するためには，噴流の発達領域 が広範囲に及ぶように作用させることが重要であると言 える.

\section{5. 結論}

本研究は，密度成層場における噴流の海水混合効果を 評価するために，染料を用いた流体の可視化による画像 解析手法を用いて，同条件の成層場に対して異なる噴流 を作用させた場合と異なる形状を有する密度場に対して 同条件の噴流を作用させた場合の混合効果の違いについ て水理実験により検討したものである. 本研究により得
られた結論は以下の通りである。

（1）本研究で用いた可視化手法により，成層場に噴流 を作用させた場合の流体の混合効果を時空間的に 評価することが可能となった。

（2）噴流による流体混合効果をポテンシャルエネルギ 一で整理した結果，混合効果は噴流リチャードソ ン数により整理できる可能性があること，また， 層厚の異なる成層場に同条件の噴流を作用させた 場合は発達領域が広範囲に及ぶように噴流を作用 させることが効果的であることが確認できた.

\section{参考文献}

1) 遠藤徹, 重松孝昌：港湾海域における底質の酸素消 費特性の季節変化に関する研究, 海岸工学論文集, Vol.56, No.2, pp.1051-1055, 2009.

2）佐伯信哉，岡田修平，中村孝幸：波浪エネルギーを 利用した鉛直混合促進型護岸の密度成層場における 効果について, 海洋開発論文集, Vol.25, pp.759-764, 2009.

3) 大村智宏：漁港における海水交換型構造物の開発に ついて，海洋開発論文集，Vol.26，pp.13-18，2010。

4）遠藤徹, 水田圭亮, 臼井諒, 田中宏史, 重松孝昌： 表層水供給装置による港湾海域底層の環境改善に関 する現地実験, 海洋開発論文集, pp.1117-122, Vol.20, 2010.

5）角屋浩二, 石川健二, 金山進，中瀬浩太，小谷拓： 流水発生装置による閉鎖性水域の密度成層の緩和に ついて, 土木学会論文集, Vol.54, pp.1021-1025, 2007.

6) 北真人，黒川岳司：噴流型流動促進装置導入による 貯水池内の流況と水質の変化, 土木学会論文集 B1 (水工学) , Vol.68, No.4, pp.1663-1668, 2012.

7）古城鉄也，遠藤徹：噴流による密度成層の緩和に関 する可視化実験を用いた検討，土木学会論文集 B2 (海岸工学)，Vol.69, No.2, pp.1226-1230, 2013.

\section{A STUDY ON WATER MIXING EFFECT OF JET IN DENSITY STRATIFIED FIELD USING A LIF METHOD}

\section{Toru ENDO and Tetsuya KOJO}

Sea Bottom environment in ports and harbors becomes hypoxic or anoxic condition by formation of density stratification during summer season. It is necessary to understand the mixing effect of jet in density stratified field before applying water mixing technologies in actual site.

In this study, we carried out laboratory experiments on the water mixing under density stratified field and we measured the spatial distribution and temporal changes of density by using a LIF method. The results of this study were as follows: (1) It is suggested the possibility that the mixing effect will be able to be prediction by Richardson number about a jet acting on the density stratified field. (2) It is found that to supply a jet in such a way that the extent of the impact of jet becomes widely was effective for the relaxation of density stratified field. 